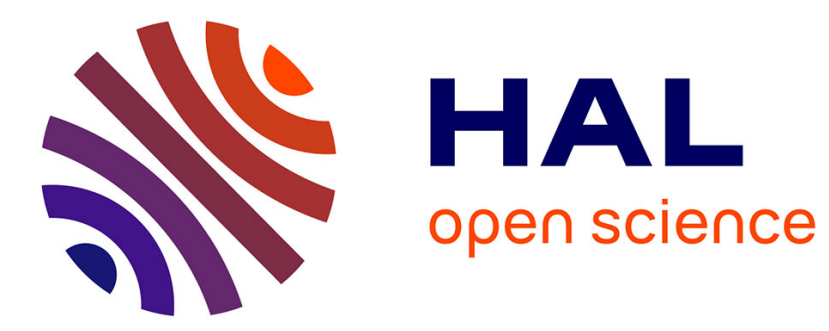

\title{
Parenting Support in France: Policy in an Ideological Battlefield
}

Claude Martin

\section{To cite this version:}

Claude Martin. Parenting Support in France: Policy in an Ideological Battlefield. Social Policy and Society, 2015, 14 (4), pp.609-620. 10.1017/S147474641500024X . halshs-01178946

\section{HAL Id: halshs-01178946 https://shs.hal.science/halshs-01178946}

Submitted on 21 Jul 2015

HAL is a multi-disciplinary open access archive for the deposit and dissemination of scientific research documents, whether they are published or not. The documents may come from teaching and research institutions in France or abroad, or from public or private research centers.
L'archive ouverte pluridisciplinaire HAL, est destinée au dépôt et à la diffusion de documents scientifiques de niveau recherche, publiés ou non, émanant des établissements d'enseignement et de recherche français ou étrangers, des laboratoires publics ou privés. 
Parenting Support in France: Policy in an Ideological Battlefield

Claude Martin

Social Policy and Society, FirstView Articles, pp 1-12

doi: 10.1017/S147474641500024X, Published online by Cambridge University Press 09 Jun 2015

\section{Parenting Support in France: Policy in an ideological battlefield}

\section{Abstract:}

Since the beginning of the 1990s, a set of measures and interventions has been progressively implemented in France under the heading of 'parenting support' (soutien à la parentalité). The aim of this article is to describe this policy process in France in order to understand the drivers, instruments and actors at work, and also to highlight the controversies and ideological roots of the policy and its framing. We argue that parenting support policy is the result of a complex process engaging a potent combination of old and new ideas, objectives and instruments which involve political and ideological contestation. The current turn to parenting in France is mainly a recalibration of previous experiences that were themselves also the site of important contradictions and controversies.

Since the beginning of the 1990s, a set of measures and interventions has been progressively implemented in France under the heading of 'parenting support' (soutien à la parentalité). Initially originated by civil society and associations at local level, these interventions have received the financial support of public authorities at both national and local level, and have become institutionalised. Some high-level civil servants now even consider parenting support to be a 'new pillar' of French family policy (Jacquey-Vazquez et al., 2013).

The aim of this article is to describe this policy process in France in order to understand the drivers, instruments and actors at work, and also to highlight the controversies and ideological roots of the policy and its framing. We argue that parenting support policy is the result of a complex process engaging a potent combination of old and new ideas, objectives and instruments which involve political and ideological contestation. Consequently, its conceptualisation and policy form is far from being a foregone conclusion. This uncertain outcome is partially due to the plasticity of the concept of parenting, which is rooted in a wide range of disciplines (from anthropology to psychoanalysis, from law to sociology), and used by a variety of actors (politicians, professionals, the media) (Martin, 2012). Such flexibility engenders many misunderstandings but also allows the various actors plenty of room for manoeuvre in defending their respective positions. Parenting, as a neologism (in both English and French), is thus close to what Paul Bernard (1999) and Jane Jenson (2014) call a 'quasiconcept' - something Jenson (2014: 4) describes as "a hybrid, making use of empirical analysis, but simultaneously characterised by an indeterminate quality that makes it adaptable to a variety of situations and flexible enough to follow the twists and turns of policy, that everyday politics sometimes makes necessary".

The empirical material is based on a systematic analysis of official reports at national and international level, as well as interviews with 20 experts and high-ranking civil servants involved in this policy domain in France and 20 professionals in charge of implementing the 
policy at local level ${ }^{1}$. The goal was to identify the main ideas, objectives, intellectual references and methods. To complement this material, we have also analysed the history of this policy, tracing previous experiences and interventions which- although not defined as parenting support - unquestionably represent roots and references. We argue that, in the French context at least, the current turn to parenting is mainly a recalibration of previous experiences that were themselves also the site of important contradictions and controversies. In bringing these to light, we see that the current battle of ideas and lines of conflict are resonant of long-existing contestations between a range of actors but especially policy makers, politicians and lobby groups.

As in many other European nations, the first difficulty to be resolved in order to appreciate the very existence of a parenting support policy is that of defining its scope. If the objective were literally to offer parents support and guidance in their parental role, we might expect a fairly straightforward definition. But in fact, the generic formulation opens up a huge field of interventions - the frontiers of which are difficult to pin down as they traverse many areas of public policy: childhood and family policy, education, child protection and juvenile justice, even policies on disease prevention and health promotion or employment - to mention only the principal fields. Definition of the scope of this policy is, however, crucial to evaluating and comparing not only the reach of actions but also the level of public spending mobilised for parenting support.

To mark out the perimeter of the sector, several authors have suggested definitions and principles that establish the boundaries of what the generic term 'parenting support' covers. In the 2012 report prepared by the advisory body the Conseil d'Analyse Stratégique (Council for Strategic Analysis), Marie-Pierre Hamel and Sylvain Lemoine put forward the three principles that guided them in producing their inventory of international experiences: "...these programmes must, first and foremost, address parents", and not just children; "...they explicitly target the improved well-being of both child and parents" ; and lastly, these interventions "seek to act on parental skills" (Hamel et al 2012: 9). In this they draw from Mary Daly's work which suggests the following definition of parenting support as: "organised services/provisions oriented to affect how parents execute their role as parents by giving them access to a range of resources that serve to increase their competence in childrearing" (Daly, 2013a: 162). This leads to the exclusion from parenting support services of early years' childcare and education, insofar as its primary objective is not how the parental role is fulfilled. Child-related financial transfers as well as parental leave would also be excluded from parenting support in Daly's definition, because these instruments seek neither to prescribe behaviours nor to intervene in relationships between parents and children.

Without delving deeper into the list of definitions suggested by the parenting support literature (see also Boddy et al., 2009; Lewis, 2011; Gillies, 2012; Ramaekers and Suissa, 2012; Richter and Andresen, 2012), a consensus is emerging on a number of key points, prioritising interventions centred on how parents care for their children and fulfil their role

\footnotetext{
${ }^{1}$ This paper is based on research funded by the French ANR (Agence nationale de la recherche) as part of the ORA-funded project : 'Governing new social risks: Policies towards children and their parents'. ANR-10ORAR-005(Martin et al. 2014).
} 
and responsibilities, which explains why parental practice, childrearing behaviours, and interactions with their children have become central.

\section{The French 'turn to parenting'}

Like other European countries presented in this issue, we argue that French family policy has also been turning towards parenting since the beginning of the 1990s. The chronology presented in Figure 1 summarises some of the milestones in this policy process since the mid1980s, distinguishing between new institutions, important official national and international reports, and some related political events and controversies.

Figure 1: The French 'turn to parenting': Chronological milestones and key events (insert here the figure)

Two main turning points are underlined. The first, following from the 1998 'Family Conference $^{2}$, involved the creation of a specific instrument for parenting support in terms of a network to coordinate and optimise diverse local initiatives: Réseau d'écoute, d'appui et d'accompagnement des parents (REAAP parents' counselling, support and mentoring network). The second occurred in 2010 with the creation of the Comité national de soutien à la parentalité (National parenting support committee). This was then and remains the official current governance body for parenting policy as such.

The first step undoubtedly came about as a consequence of the UN Convention on the Rights of the Child adopted by the UN in 1989 and ratified by France in 1990. Among other consequences of the Convention was a debate concerning the replacement of the notion of parental authority with that of parental responsibility. After the 1998 Family Conference, the (left wing) Jospin Government decided to promote a specific instrument -the REAAP network. At least part of the intention was to thwart the right wing proposal to punish 'bad' parents considered incompetent and responsible for youth delinquency. A variety of interventions were in fact contained within the REAAP umbrella: effectively it was and is a one-window portal for families to access information and advice (Point information famille or Maison des familles); lectures and discussion fora on childhood, adolescence and youth; family mediation; organising parental support for children's homework through CLAS (Contrats locaux d'accompagnement à la scolarité); and the creation of places welcoming children and parents (or grandparents), and on a voluntary basis, to facilitate communication between each other under professional supervision (LAEP - Lieu d'accueil parent-enfant). The REAAP networks were however very unevenly developed and distributed across the national territory. The person in charge of the parenting support interventions at the Caisse nationale des allocations familiales (CNAF) - the family branch of the social security system at départemental and national level - support this idea of a turn:

\footnotetext{
${ }^{2}$ Since 1996, family conferences have been organised every year under the authority of the Prime Minister, to present - and discuss with social partners - major governmental family policy orientations, plans and reforms.
} 
“1998/1999 was really the first step, with the role of the Child and Family Institute and the creation of the REAAP. At the beginning, the main idea was to support initiatives which were emerging at the time in various associations and localities, and to coordinate them thanks to a network. The will of the state was to federate these initiatives and to answer the requests of the associations to be better recognised. The Délégation interministérielle à la famille was in charge of the coordination."

The second step, in 2010, followed a series of evaluations (in particular the fairly critical Cour des comptes report of 2009) and, as mentioned, led to the government deciding to establish the Comité national de soutien à la parentalité, a new body to coordinate and guide the disparate local parenting support initiatives. This official committee, chaired by the minister in charge of the family, and consisting of 35 representatives from the main social partners, pressure groups and lobbies, is charged with the difficult task of defining and negotiating the policy field (Martin, 2014). Unable (or unwilling) to fund the policy, the government suggested that its governance be divided between state control and national-level supervision, with financial support and expertise from the CNAF. In order to support developments, the CNAF decided to double the parenting support policy budget from 2012, increasing it from $€ 75$ to 150 million per year. When set in context however, this has to be seen as a modest investment corresponding to only $0.2 \%$ of the global budget devoted to family allowances (apart from housing). Of the $€ 150$ million, the State only invests $€ 18$ million; local authorities contribute some $€ 50$ million and the social security system (the CNAF) contributes the remainder.

Over the past 20 years, then, a slow but undeniable process of institutionalisation of parenting support has taken place. In this process, parenting support policy has been driven forward by all political actors and governments, all the while challenged by the need to maintain a balance between empowering and supporting all parents in a universal, service-oriented way, and controlling - or even punishing - those seen as irresponsible or incompetent (Martin, 2013). Behind this opposition between universalism and targeting lurk other issues, including social control of 'dangerous classes' but also moral disapproval and control of working-class mothers (Garcia, 2011; Neyrand, 2011). In this complex interplay, the media has played an important part in making insecurity an ubiquitous threat, particularly during the 2002 campaign for the presidential and general elections. This context reinforced right-wing proposals such as that of sanctioning those parents held responsible for a 'juvenile delinquent crime wave' by stopping payment of their family allowances (Martin, 2003). Even left-wing politicians were pushed to recognise the so-called parental responsibility deficit.

More recently, the polarity between political parties has been revived. As the Minister of the Family (between May 2012 and March 2014) in the previous left-wing government, argued in one of our interviews:

"For the previous (right wing) government, parenting policy was geared towards the stigmatisation of families. To put it somewhat crudely, it was because the parents were not good parents and so, the sanctions road was the preferred option - we even went as far as the notorious 'décret Ciotti' - which advocated the withdrawal of family benefit 
payments where children's school attendance was poor. When I arrived, I considered that we had to turn this problematic on its head, by saying: it is not up to us to stigmatise families but rather, on the contrary, to admit that at some point, in the process of educating their children, they may come up against questions, difficulties, and problems - and the issue is to discover how we - that is, we the state, we the institutions, we the local authorities - might try to offer responses."

A high-ranking civil servant in the Inspection générale des affaires sociales illustrates in another interview this political balance and the way high-civil servants have to situate their policy framing:

"For our report, we decided to exclude all the coercive or social control interventions, explicit or implicit, to normalising parental behaviours perceived to be deviant or irresponsible. But, according to the political majority, this policy already switched from a rather friendly and preventing policy initially to a coercive and targeted policy towards at-risk families".

But she also insists on the current strategy to avoid this ideological battle.

"We remain faithful to the ideal of republican universality, but we take care of the necessity to support more people in higher need, in a sort of proportioned universalism”.

French parenting support policy clearly shares with that of England a sense of punitive accountability of parents who are deemed 'incompetent', and therefore guilty of their offspring's poor behaviour. As evidence consider the rise of the theme of parental accountability in the late 1990s in both countries and the introduction of parenting orders in the early 2000s in England and contrats de responsabilite parentale in 2006 in France. Yet there are major differences between France and England on two points, at least. First, it is governmental will in France (initially left-of-centre, though continued through the political changes of the 2000s) to promote low-cost territorial measures calling on NGO mobilisation and a parent empowerment approach, and secondly, in France very little recourse is made to the evidence-based programmes that are so popular in England (and the Netherlands to take another example). The non-adoption of such programmes in France is mainly due to resistance among childhood and family professionals, particularly following the publication of an Inserm summary report on the knowledge acquired on early childhood difficulties and their links to high-risk behaviours in adolescence (Inserm, 2005). In effect, the attempt to identify behavioural deviance at preschool level has been strongly rejected by a large number of professionals in the field of childhood and family Their opposition to such a preventive strategy was driven by a refusal of labelling and a preference for more clinical than epidemiological data. Many psychoanalysts and child psychiatrist supported this mobilisation named "Pas de 0 de conduit pour les enfants de 3 ans" (http://www.pasde0deconduite.org/).

Last but not least, it is clear that the rolling out of parenting support has been supported by international initiatives and reports at EU level, in particular the Council of Europe, which have helped shape objectives and instruments. Even though this parenting support policy like all other social and family policies - is a matter for individual member states, it is 
undeniable that the European Union and Council of Europe have facilitated the circulation of ideas and methods, thus contributing to the definition of orientations, and by identifying best practice that in turn helps draw the outline for the development of national policy. Three publications that have made major contributions to the definition of this policy in the course of the 2000s in France are worthy of mention: the report of the committee of experts on childhood and the family, under the auspices of the Council of Europe (Daly 2007); the report from the European Network of National Observatories on Childhood (ChildONEurope 2007); and lastly, in 2012, a report commissioned by the European Commission from RAND Europe 3 (European Commission, 2012).

The RAND report goes further still, putting parenting support policy into perspective and linking it to the idea of the necessary shift towards the social investment state and the defence of human capital, with explicit references to the works of Anthony Giddens, Gösta EspingAndersen and even James Heckman, Nobel Memorial Prize winner in Economics with his idea of 'capitalising later in life' on investment in early childhood (avoidance of future expenditure) (European Commission, 2012: 7 idem). One of the high-ranking civil servant respondents in the Inspection générale des affaires sociales confirmed this social investment argument in the French case:

"To convince, it is necessary to resort to the foreign experiments, but also to speak in terms of empowerment and social investment. I think that we have to change vocabulary and adopt a budgetary rhetoric and for example say that it is a profitable social investment for the community".

The RAND report also defends the idea that the success of the child is best guaranteed by the support he or she receives from parents (which is placed well ahead of that of the community or local authority). This is why it is seen to be more effective to target the educational and behavioural practices of parents, as well as to promote evidence-based programmes. Moving on to discuss initiatives adopted at European level - their methods and financing modes as well as results - this report is clearly presented as a prescriptive script for policy yet to come in the member states. These and other developments are seen to be quite persuasive. The interviews suggest that the idea of a common European parenting support policy is beginning to gain support among some high-ranking French civil servants.

While all of these factors undoubtedly play a role, it would be too easy, and over-simplistic, to reduce the opposition between empowerment and control to a single political argument or a simple effect of alternating left- and right wing governments. Things are more complex and, as we shall see now, deeply rooted in French welfare state history.

\footnotetext{
${ }^{3}$ An international think-tank of experts, founded in California in 1945, issuing expertise on many research and development questions.
} 


\section{Historical roots of the parenting support orientation}

One key issue is the extent to which parenting support policy is really new. When looking back over the years since the end of the $18^{\text {th }}$ century, it becomes clear that the idea of controlling and supporting mothers and fathers in their respective parenting practices is not new at all (Donzelot, 1977; Joseph and Fritsch, 1977). And contrary to what might be expected as a conclusion from the first section, we argue that these roots, old ideas and orientations still play a major part in helping to understand current French parenting support policy. From the $18^{\text {th }}$ century on, each step in the development of an inter-relationship between parents and the state delineates the frontlines of the conflict between protagonists of different interventions.

One could take any number of historical examples of the normative framework which justified the giving of 'advice' and injunctions aimed at protagonists of the parental role ever since the late 18th century, which in essence set the public boundaries and expectations for the parenting role. Yet, at this time, mothers and fathers, paternity and maternity, were clearly distinguished, undoubtedly for the most part because of the extremely rigid division of gender roles. Because of this, mothers and fathers generated contrasting views and different intervention strategies. Furthermore, the issues were framed in terms of the family rather than parenting - a term which had yet to be coined.

As regards fathers, and because they were given authority, the main issue for the state and the public authorities concerned the opportunity (or necessity) of standing in for them in the event of absence, failure or danger. But the lion's share of standards and recommendations was reserved for mothers, and especially those judged as weakest, namely young mothers. Sometimes this was in a bid to support and help them cope with their new condition, often from a public health and preventive perspective. Yet this was also a normative pressure and it took varying forms depending on the social identity of those involved, such as young working-class mothers who were considered even less well prepared (by virtue of their class background) for adopting best practice. In the eyes of certain defenders of family values and of human capital, young single mothers were a greater risk because, left to their own devices, they were seen to be at risk of committing an act from which there is no return (abortion or abandonment). This group, therefore, occupied a sort of bottom-rank in parental competence. ${ }^{4}$

In the story of this normative framing, the Troisième République (1870-1940) and the advent of the social sciences have played a major role in regulating the balance between the respective roles of family and state, within a context of struggle between the two versions of French familialism (church familialism vs. state familialism) (Lenoir, 2003). The pioneers of the Durkheimian school (for a development see Durkheim, 1975; Martin, 2004) thus underlined the shrinking of the perimeter of functions belonging traditionally exclusively to family and parents, most of them being transferred to the state.

\footnotetext{
${ }^{4}$ For example, under the Third Republic a few hygienists founded both obstetrics and 'homes' for filles-mères (young single mothers) in an attempt to guarantee the survival of children abandoned by their fathers - as well as to avoid the practice of abortion and the taking into care of children, by helping and supporting these mothers (Lefaucheur and Martin, 1995).
} 
Yet, during the Troisième République, it is undeniably psychoanalysis that legitimises this parental 'mission', defends its incontrovertible exclusivity, establishes its responsibilities and provides most of the framework for action (Castel, 1973). The inter-war period was particularly conducive to the promulgation of such views of the parental role and was witness to ongoing struggle between different 'family values entrepreneurs' over its definition. Of particular relevance was the creation at the start of the 1930s, of l'Ecole des parents, the objective of which, as originally formulated in 1929, was: "to teach parents to educate and instruct one another so that their children become future social and moral values" (Donzelot, 1979: 181). In comparison with earlier periods, the situation of single mothers was, for l'Ecole des parents, less oriented to paternalistic protection of the vulnerable mother and child than to defending family and parents - from a prevention and advisory perspective - against intrusion by the state and its agents. The latter was considered excessive by the Social Catholic interests underpinning l'Ecole des parents. It is somewhat ironic to note that while the goal was to buttress the family against the state, l'Ecole des parents actually condoned another form of supervision of families: that by relationship professionals (especially psychoanalysts).

Other public intervention modalities can also be considered sources of inspiration for understanding the ideological struggles underpinning current parenting support policy. These include the Protection maternelle et enfantile ${ }^{5}$, some equivalent of which has existed in many countries since the World War II (Norvez, 1990). Here too we can identify relevant ideological evolution and struggles, particularly about the meaning of prevention and its capacity to counter inequalities. In his book on the history of public health, childcare and preschool policy in France, Alain Norvez identifies a change in the late 1950s. Instead of universalism, the underlying problem at this time was seen to be around targeting or concentrating effort and support on the most vulnerable. This resultant change triggered multiple reflections, particularly in terms of the risk of excessive 'social control', whereby blame-laden preventive messages and injunctions were seen to fail to bring the targeted populations to heel, sometimes even provoking resistance among them. Moreover, it is in this period that the idea of 'health promotion' (rather than prevention) arose and was defended in an influential report by Grémy and Pissaro prepared for Jacques Ralite, then Socialist French Minister for Health (Grémy and Pissarro, 1982).

We must also, as David Pioli (2006) suggests, refer to another significant moment: the opération pouponnière of the mid-1970s. ${ }^{6}$ The aim of this 1977 initiative was to reduce the number of institutional placements of children (in order to reduce the cost of placing children there as a substitute for being with their parents) and also to reduce the risks of 'hospitalism., 7 The underlying inspiration was the lessons to be learned from attachment theory, which was very popular at the time (Zazzo, 1974). Using the vocabulary of public policy analysis, Pioli evokes the resurgence of a specific frame of reference that characterised childhood-targeted policies in the late 19th century: the idea of safeguarding human capital within a 'community

\footnotetext{
${ }^{5}$ A service organised at the local level (in each département) to assure the health protection of mother and child.

${ }^{6}$ Opération pouponnière refers to an initiative launched by Simone Veil to promote the positive treatment of children (bientraitance), as opposed to treating them in terms of the risk of abuse.

${ }^{7}$ A pediatric diagnosis used in the 1940s to describe a form of depression of children who wasted away while in long-term hospitalisation.
} 
of public policies'. At the time of adoption of this opération pouponnière by the Direction de l'action sociale (the department for social welfare within the French Ministry of Health) in 1977, such well-known psychologists and figures as Myriam David, Geneviève Appell and Danièle Rapoport were working for the ministry.

During a 1987 review of this operation, as part of a study entitled 'Children's homes and parenting', a number of reflections were undertaken on 'the possibilities for maintaining parental functions within a situation of family breakdown'. These reflections led to a whole series of initiatives, eventually resulting in the drafting of future parenting support policy. As Pioli (2006: 18) comments: "The dynamic resulting from the focus on the interests and wellbeing of the child was to go hand in hand with a significant change in the way parents were represented. No longer were they perceived as being at fault, with their failures legitimising a degree of parental substitution (by the state), but as victims, struggling in particular with the need to construct a parental identity despite the suffering of the child".

\section{Conclusion}

In this paper we have argued that recent parenting support policy in France extends and integrates the influence of old elements in a new way. In effect, initiatives of the past (in terms of objectives, intervention methods and public action instruments) continue to inspire current interventions, even though there is no doubt that the configuration has evolved considerably and there is even the possibility that the actors of the present do not necessarily reference earlier forms of intervention. Nevertheless, parenting support policy today, as in the past, is formulated in terms of a range of possible dominant intervention logics that are used as resources in a struggle in which the outcomes are not entirely predictable.

Our analysis of the French case leads to three lessons. The first is that there is nothing especially new in the will of the public authorities - and of certain scholarly, expert and practitioner circles - to seek to control, supervise and/or guide parental practice. The second lesson is that the socio-political context is crucial to understanding the meaning to be attributed to practices and interventions. Contextualising the provisions allows one to see the balance being sought between the protection of privacy and resistance to the state's intrusion and paternalism, on the one hand, and the need to defend both collective issues and the general interest on the other. Contestation and conflicts between the two general orientations have become stronger over time. And although these oppositions are not set in stone, they continue to give rise to unequal power relations that are still at work today.

A third lesson that should be better documented in further work concerns the shift from a gendered normative framework, distinguishing clearly between father and mother, to a construction of messages addressed to parents as gender neutral. For Mary Daly (2013b), the apparent gender neutrality of the term 'parent', with regard to the respective roles of mother and father, can correspond to at least two ways of thinking: either the will to show that the parental role is (or must be) less and less gendered or, the intention of neglecting - or even denying - the pertinence of gender differences in parenting matters (gender blind). This is another very conflictual issue in the French context, as highlighted by the La manif pour tous 
social movement, which contests both the adoption of mariage pour tous (same sex marriage), and the initiative aimed at raising children's awareness of gender equality issues at school ( $l$ 'ABCD de l'égalité). ${ }^{8}$ This conservative movement condemns a hypothetical 'gender theory' at the same time as it defends 'natural' sex differences and the necessity of distinguishing between mother and father. They only have a problem with a (apparently gender neutral) parenting policy when they believe it leaves the door open to gender confusion.

Lastly, we could put forward the hypothesis that parenting support (re)appeared in a context where the hedonistic and individualistic approach that dominated between 1970 and 1990 was becoming blurred. The main issue nowadays is the apparent collapse of parental capacities, or the condemnation of parental failure in the context of the uncertainties of the present time, particularly with regard to the future of the new generations.

\section{Bibliography}

Bernard, P. (1999) 'La cohésion sociale: critique dialectique d'un quasi-concept', Lien social et Politiques, 41, 47-59.

Bianco, J-L and Lamy, P. (1980) L'aide sociale à l'enfance demain. Contribution à une politique de réduction des inégalités, Rapport remis au ministère de la santé et de la sécurité sociale, Paris: Imprimerie nationale.

Boddy, J., Statham, J., Smith, M., Ghate, D., Wigfall, V. and Hauari, H. (2009) International perspectives on parenting support non-English language sources, Research Report No DCFR-RR114, London: Department for Children, Schools and Families.

Castel, R. (1973) Le psychanalysme, Paris: Flammarion.

ChildONEurope (2007) Survey on the role of parents and the support from the governments in the European Union, Florence, Italy: ChildONEurope.

Cour des Comptes (2009) Rapport public annuel 2009, Paris: La Documentation française.

Daly, M. (ed.) (2007) Parenting in Europe: a positive approach, Strasbourg: Council of Europe.

Daly, M. (2013a) 'Parenting support policies in Europe', Families, Relationships and Societies, 2, 2, 159-74.

Daly, M. (2013b) 'Parenting support: Another gender- related policy illusion in Europe?', Women's Studies International Forum, 41, 223-30.

Donzelot, J. (1977) La police des familles, Paris: Les éditions de Minuit.

Durkheim, E. (1975) 'La famille conjugale', in E. Durkheim, Textes : Fonctions sociales et institutions, Paris: Les éditions de Minuit, 35-49.

European Commission (2012) Parenting support policy brief, Brussels: Employment, Social Affairs and Inclusion.

\footnotetext{
${ }^{8}$ See http://www.cndp.fr/ABCD-de-l-egalite/accueil.html.
} 
Garcia, S. (2011) Mères sous influence. De la cause des femmes à la cause des enfants, Paris: éditions La découverte.

Gillies, V. (2012) 'Family policy and the politics of parenting: From function to competence', in M. Richter and S. Andresen (eds.), The politicization of parenthood. Shifting private and public responsibilities in education and childrearing, Dordrecht: Springer, 13-26.

Grémy, F. and Pissarro, B. (1982) Propositions pour une politique de prévention. Rapport au ministre de la Santé, Paris: La Documentation française, collection des rapports officiels.

Hamel, M-P, Lemoine, S. and Martin, C. (eds.) (2012) Aider les parents à être parents. Le soutien à la parentalité, une perspective internationale, Rapport and documents $\mathrm{n}^{\circ} 50 \mathrm{du}$ Centre d'analyse stratégique, Paris: La Documentation Française.

Inserm (2005) Troubles des conduites chez l'enfant et de l'adolescent, Expertise collective. Paris: éditions Inserm.

Jacquey-Vazquez, B., Raymond, M. and Sitruk, P. (2013) Evaluation de la politique de soutien à la parentalité (MAP -volet1), Tome I et II. Rapport, Inspection Générale des Affaires Sociales RM2013-015P, Février.

Jenson, J. (2014) 'Reworking the socials: Four intersecting concepts for modernising social policy', Working paper prepared for the International Conference, Assessing the social investment strategy, Institut des hautes études en administration publique (IDHEAP) Lausanne, 10-11 April, 2014.

Joseph, I. and Fritsch P. (1977) Disciplines à domicile. L'édification de la famille, FontenaySous-Bois : Recherches.

Lefaucheur, N. and Martin, C. (eds.) (1995) Qui doit nourrir l'enfant dont le père est absent. Recherche sur les fondements des politiques familiales en Europe. Angleterre, France, Italie, Portugal, Paris: CNAF.

Lenoir, R. (2003) Généalogie de la morale familiale, Paris: Seuil.

Lewis, J. (2011) 'From Sure Start to Children's Centres: An analysis of policy change in English early years programmes', Journal of Social Policy, 40, 1, 71-88.

Martin, C. (2004) 'Les fonctions de la famille', Cahiers français, 322, Paris: La Documentation française, 29-33.

Martin, C. (2003) La parenté en questions. Perspectives sociologiques, Rapport pour le Haut Conseil de la Population et de la famille, Paris: La Documentation Française.

Martin, C. (2012) 'Le soutien à la parentalité. Généalogie et contours d'une politique émergente' in M-P. Hamel, S. Lemoine and C. Martin (eds.), Aider les parents à être parents. Perspectives internationales, Rapport and documents n 50 du Centre d'analyse stratégique, Paris: La Documentation Française, 25-50. 
Martin, C. (2013) 'The invention of a parenting policy in the French context: Elements for a policy tracing', in J. G. Ferrer and I. Monsonís Payá (eds.), Sustainability and transformation in European social policy, Oxford: Peter Lang Publishing, 179-97.

Martin, C. (ed) (2014) Être un bon parent. Une injonction contemporaine, Rennes: Presses de l'EHESP.

Martin, C., Campéon, A., Keppens, D. and Rothé, C. (2014) Gouverner les nouveaux risques sociaux. Le cas des politiques en direction de l'enfance et de la parentalité dans les Etatsprovidence Européens. Rapport de recherche pour l'Agence nationale de la recherche. Programme ANR 10 ORA 005, Paris: ANR.

Neyrand, G. (2011) Soutenir et contrôler les parents. Les dispositifs de parentalité, Toulouse: Erès.

Norvez, A. (1990) De la naissance à l'école. Santé, modes de garde et pré-scolarité dans la France contemporaine, Paris: PUF-INED.

Pioli, D. (2006) 'Le soutien à la parentalité : entre émancipation et contrôle', Sociétés et Jeunesses en difficulté [Online Journal], 1 | Spring, http://sejed.revues.org/106

Ramaekers, S. and Suissa, J. (2012) The claims of parenting. Reasons, responsibility and society, Dordrecht: Springer.

Richter, M. and Andresen, S. (eds.) (2012) The politicization of parenthood. Shifting private and public responsibilities in education and childrearing, Dordrecht: Springer.

Zazzo, R. (ed) (1974) L'attachement, Neuchâtel: Delachaux et Niestlé. 
Figure 1: The French 'turn to parenting': Chronological milestones and key events
1980
1989
1998
2002
2010
2013

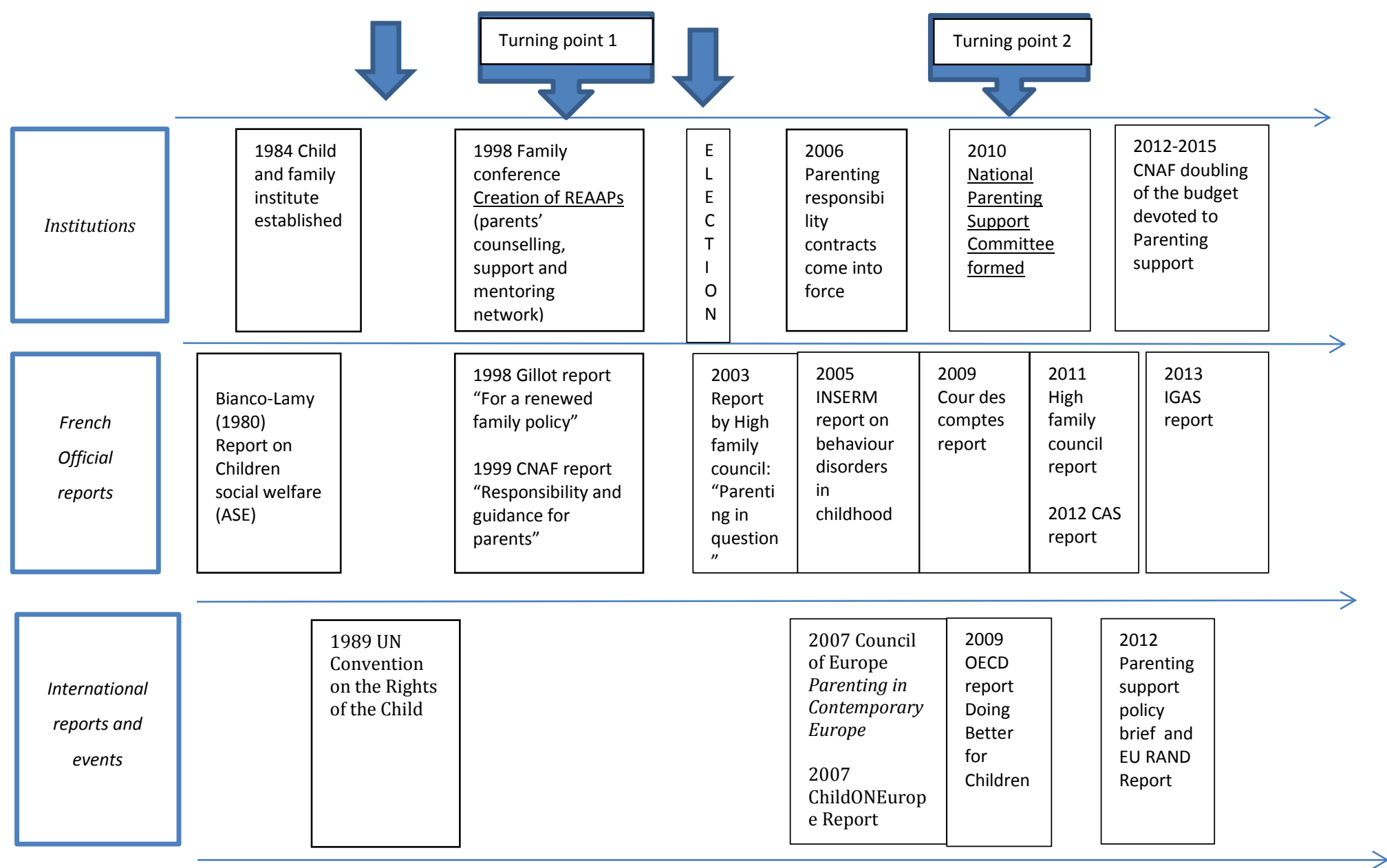

